\title{
Adenosine Diphosphate-Ribosylation of G-Actin by Botulinum C2 Toxin Increases Endothelial Permeability In Vitro
}

\author{
N. Suttorp," M. Polley, ${ }^{\star}$ J. Seybold, ${ }^{\star}$ H. Schnittler,” W. Seeger, F. Grimminger, and K. Aktories \\ ${ }^{*}$ Department of Internal Medicine, Justus Liebig-University, D-6300 Giessen; ${ }^{\ddagger}$ Department of Anatomy and Cell Biology, \\ Phillips University, D-3550 Marburg; and ${ }^{\S}$ Department of Pharmacology, University of Essen, D-4300 Essen, Germany
}

\begin{abstract}
The endothelial cytoskeleton is believed to play an important role in the regulation of endothelial permeability. We used botulinum C2 toxin to perturb cellular actin and determined its effect on the permeability of endothelial cell monolayers derived from porcine pulmonary arteries. The substrate for botulinum C2 toxin is nonmuscle monomeric actin which becomes ADPribosylated. This modified actin cannot participate in actin polymerization and, in addition, acts as a capping protein. Exposure of endothelial cell monolayers to botulinum $\mathrm{C} 2$ toxin resulted in a dose- (3-100 $\mathrm{ng} / \mathrm{ml})$ and time-dependent (30-120 min) increase in the hydraulic conductivity and decrease in the selectivity of the cell monolayers. The effects of $\mathrm{C} 2$ toxin were accompanied by a time- and dose-dependent increase in ADP-ribosylatin of G-actin. G-Actin content increased and F-actin content decreased time- and dose-dependently in $\mathrm{C} 2$ toxin-treated endothelial cells. Phalloidin which stabilizes filamentous actin prevented the effects of botulinum $\mathrm{C} 2$ toxin on endothelial permeability. Botulinum $\mathrm{C} 2$ toxin induced interendothelial gaps. The effects occurred in the absence of overt cell damage and were not reversible within $2 \mathrm{~h}$. The data suggest that the endothelial microfilament system is important for the regulation of endothelial permeability. (J. Clin. Invest. 1991. 87:1575-1584.) Key words: cultured pulmonary endothelial cells $\bullet$ hydraulic conductivity $\bullet$ membrane selectivity $\bullet$ cytoskeleton
\end{abstract}

\section{Introduction}

The acute respiratory distress syndrome of the adults is characterized by a noncardiogenic pulmonary edema (1). The mechanisms of increased vascular permeability, however, are poorly understood. Already 20 years ago Majno et al. (2) provided evidence that inflammatory agents induce enhanced vascular permeability in vivo by causing endothelial cell contraction and intercellular gap formation. This concept has been extended to more recently discovered inflammatory mediators such as leukotriene $\mathrm{E}_{4}(3)$. Endothelial cell retraction was also demonstrated in vitro using cultured endothelial cell monolayers after addition of different inflammatory agents (histamine, bradykinin, thrombin, reactive oxygen species, bacterial toxins) (4-13). Circumstantial evidence suggests that enhanced

Address correspondence to Norbert Suttorp, M.D., Department of Internal Medicine, University of Giessen, Klinikstrasse 36, D-6300 Giessen, Germany.

Received for publication 31 May 1989 and in revised form 10 October 1990

J. Clin. Invest.

(c) The American Society for Clinical Investigation, Inc.

$0021-9738 / 91 / 05 / 1575 / 10 \quad \$ 2.00$

Volume 87, May 1991, 1575-1584 endothelial permeability is related to alterations of the cellular cytoskeleton $(6,7,14-16)$. Endothelial cells have been shown to contain an elaborated microfilament system, consisting of actin, myosin, alpha-actinin, tropomyosin, spectrin, and other components (17-23). Recent studies in skinned endothelial monolayers using $N$-ethylmaleimide modified myosin subfragment 1 suggest that an interaction of endothelial actin and myosin is important for the regulation of endothelial permeability (24). Moreover, endothelial cell retraction appears to be dependent on myosin-light chain kinase phosphorylation of myosin light chains (25). Additional evidence for a role of the endothelial cytoskeleton in regulating the endothelial permeability comes from studies with the microfilament disrupting substance cytochalasin $\mathrm{D}(26)$. This agent was shown to reversibly increase the permeability of endothelial cell monolayers. This effect was accompanied by gap formation between cells and dearrangement of endothelial actin filaments (26).

Botulinum $\mathrm{C} 2$ toxin is a binary toxin and consists of two components, C2I and C2II $(27,28)$. Whereas $\mathrm{C} 2 \mathrm{I}\left(M_{\mathrm{r}} 50,000\right)$ possesses ADP-ribosylating activity $(27), \mathrm{C} 2 \mathrm{II}\left(M_{\mathrm{r}} 100,000\right)$ appears to be involved in the binding of $\mathrm{C} 2 \mathrm{I}$ to the eukaryotic cell surface and the transfer into the cell (28). Botulinum $\mathrm{C} 2$ toxin ADP-ribosylates in arginine 177 nonmuscle actin but not skeletal muscle actin $(27,29-31)$. The toxin modifies actin in its monomeric G-form, while polymerized F-actin is a poor substrate (27). ADP-ribosylation inhibits the ability of actin to polymerize $(27,29)$. Furthermore, this modification turns actin into a capping protein which binds to the barbed end of actin filaments thereby inhibiting the polymerization of unmodified actin $(27,32)$. The specific action of botulinum $\mathrm{C} 2$ toxin on actin qualifies the toxin as a new tool to study the role of actin in various cell functions (33).

Using botulinum $\mathrm{C} 2$ toxin we started to probe the role of actin in the regulation of the permeability of endothelial monolayers in a well-defined in vitro system (12).

\section{Methods}

Materials. Tissue culture plasticware was obtained from Becton-Dickinson, Heidelberg, FRG. Medium 199, FCS, HBSS, trypsin-EDTA-solution, Hepes, and antibiotics were from Gibco, Karlsruhe, FRG. Collagenase (type CLS type II) was purchased from Worthington Biochemical Corp., Freehold, NJ. Gelatin from porcine skin type I, calf thymus DNA (type 1), DNAse (type 4), bovine muscle actin, glutaraldehyde grade II, cytochalasin D (CD), thymidine, leukopeptin, phalloidin, and PMSF were obtained from Sigma Chemical Co., Munich, FRG. Polycarbonate micropore filter membranes $(25 \mathrm{~mm}$ diameter, $5 \mu \mathrm{m}$ pore size) were purchased from Nuclepore GmbH, Tübingen, FRG. ${ }^{3} \mathrm{H}_{2} \mathrm{O}(1$ $\mathrm{mCi} / \mathrm{g}$ ) was supplied by New England Nuclear, Dreieich, FRG, and methyl- $\left[{ }^{14} \mathrm{C}\right]$-albumin $(0.026 \mathrm{mCi} / \mathrm{mg})$ and $\left[{ }^{32} \mathrm{P}\right]-\mathrm{NAD}$ were from Amersham Buchler, Braunschweig, FRG. Rhodamine-labeled phalloidin was obtained from Molecular Probes, Inc., Junction City, OR. All other chemicals used were analytical grade and obtained from commercial sources. 
Botulinum C2 toxin was prepared and activated essentially as described (28)

Pulmonary artery endothelial cells were obtained from freshly slaughtered pigs by exposure to $0.1 \%$ collagenase for $12-15 \mathrm{~min}$ (34$36)$. Endothelial cells were isolated, characterized, maintained, and dispersed as previously described (37-39).

Endothelial cell monolayer on polycarbonate filter membranes. Polycarbonate filter membranes were coated with gelatin, exposed to glutaraldehyde, and sterilized as previously described (12). The coated filter membranes were placed in the bottom of a petri dish, about 2 $\times 10^{6}$ cells were seeded on the filter in medium $199 / 10 \%$ FCS and allowed to adhere for $3 \mathrm{~h}$. Additional $10 \mathrm{ml}$ of medium were then added to the petri dish. Thereafter, the monolayers were fed every other day and used $\sim 6 \mathrm{~d}$ after plating.

Determination of hydraulic conductivity. A confluent filter membrane was mounted in a modified chemotaxis chamber. The upper and lower compartments were filled with HBSS supplemented with $0.25 \%$ albumin. One port to the upper compartment is for substitution of filtrated volume and for application of pressure and one port is for the addition of reagents. The lower compartment of the system is part of a semiclosed perfusion system (total volume, $10 \mathrm{ml}$ ). A roller pump provides a flow of $10 \mathrm{ml} / \mathrm{min}$. The circulating fluid drips into a $1-\mathrm{ml}$ capillary; the height of the fluid level in this capillary directly corresponds to the volume filtrated through the cell monolayer. A filtrated volume of $10 \mu \mathrm{l}$ can reliably be measured. The entire system is kept at $37^{\circ} \mathrm{C}$ by a heated water bath (12). A hydrostatic pressure of $10 \mathrm{~cm} \mathrm{H}_{2} \mathrm{O}$ was continuously applied to the upper side of the cell monolayer. The filtration rate across the endothelial monolayer was continuously determined (12)

Selectivity of the endothelial cell monolayer. For calculation of this parameter $100 \mathrm{nCi}^{3} \mathrm{H}_{2} \mathrm{O}$ and $100 \mathrm{nCi}\left[{ }^{14} \mathrm{C}\right]$-albumin were added to the upper compartment. The amount of ${ }^{3} \mathrm{H}_{2} \mathrm{O}$ and $\left[{ }^{14} \mathrm{C}\right]$-albumin in the lower compartment was continuously measured in a Ramona LS-5 radioactivity monitor (Raytest, Heidelberg, FRG) consisting of a flowthrough cell, a splitter/mixer, and an IBM-PC for data calculation (for details see reference 12). The endothelial cell monolayer selectivity (MS) was calculated every $5 \mathrm{~min}$ on the basis of ${ }^{3} \mathrm{H}_{2} \mathrm{O}$ and $\left[{ }^{14} \mathrm{C}\right]-$ albumin in the upper and lower compartments of the filter system. Calculations were done as follows (see also reference 12): $\mathrm{MS}=1-(A /$ $B \times D / C$ ). $A$ and $C$ are the differences (in counts per minute per milliliter) of $\left[{ }^{14} \mathrm{C}\right]$-albumin and ${ }^{3} \mathrm{H}_{2} \mathrm{O}$, respectively, in the lower compartment of the system between time points $x$ and $x+5$ min, multiplied by the volume of the lower compartment. $B$ and $D$ are the sums (in counts per minute per milliliter) of $\left[{ }^{14} \mathrm{C}\right]$-albumin and ${ }^{3} \mathrm{H}_{2} \mathrm{O}$, respectively, in the upper compartment at time points $x$ and $x+5$ min, divided by 2 (12). Calculation of $A / B$ yields the albumin clearance; calculation of $C / D$ yields the water clearance.

The clearance of albumin or water consists of diffusive and convective parts. With respect to actual volume of fluid transferred from upper to lower compartments diffusion predominates in resting sealed endothelial cell monolayers. The ratio convection to diffusion is $1: 4$ when hydraulic conductivity is $0.5 \times 10^{-5} \mathrm{~cm} \times \mathrm{s}^{-1} \times \mathrm{cm} \mathrm{H}_{2} \mathrm{O}^{-1}$.

The data calculated according to $1-(A / B \times D / C)$ do not represent true albumin reflection coefficients because by the experimental approach used it is not known with certainty that, with respect to albumin transport, convection always predominates over diffusion. The equation used yields an index of membrane selectivity. Therefore, this parameter is called the selectivity of the endothelial cell monolayer.

ADP-ribosylation assay. ADP-ribosylation was performed essentially as described $(27,30,40)$. Briefly, endothelial cell monolayers were incubated in HBSS (supplemented with $25 \mathrm{mM}$ Hepes and $0.25 \%$ BSA) with different concentrations of $\mathrm{C} 2$ botulinum toxin for $60 \mathrm{~min}$ or with $50 \mathrm{ng} / \mathrm{ml}$ botulinum $\mathrm{C} 2 \mathrm{I}$ and $50 \mathrm{ng} / \mathrm{ml}$ botulinum C2II toxin for the indicated periods of time. Thereafter, cells were washed thrice and lysed in a medium containing $10 \mathrm{mM}$ triethanolamine- $\mathrm{HCl}(\mathrm{pH}$ 7.5), $0.5 \mathrm{mM}$ PMSF, $0.1 \mu \mathrm{g} / \mathrm{ml}$ leukopeptin, and $2.5 \mathrm{mM}$ EDTA. Then the preparation was frozen, thawed, homogenized, and finally used in the ADP-ribosylation assay. ADP-ribosylation of endothelial lysates was carried out in a buffer containing $10 \mathrm{mM}$ thymidine, $0.5 \mathrm{mM}$ ATP, $2 \mathrm{mM} \mathrm{MgCl}{ }_{2}, 1 \mathrm{mM}$ EDTA, $1 \mathrm{mM}$ dithiothreitol, $5 \mu \mathrm{M}\left[{ }^{32} \mathrm{P}\right]-\mathrm{NAD}$ $(\sim 5 \mu \mathrm{Ci}), 1 \mu \mathrm{g} / \mathrm{ml}$ botulinum $\mathrm{C} 2$ toxin component $\mathrm{I}$, and $50 \mathrm{mM}$ triethanolamine- $\mathrm{HCl}, \mathrm{pH} 7.4$. The reaction was started by the addition of $50 \mu \mathrm{l}$ of the endothelial lysate to give a total volume of $100 \mu \mathrm{l}$. Incubation was carried out for $1 \mathrm{~h}$ at $37^{\circ} \mathrm{C}$. The reaction was stopped by the addition of $1 \mathrm{ml}$ ice-cold TCA ( $20 \% \mathrm{wt} / \mathrm{vol})$, and the radioactively labeled proteins were analyzed by SDS-polyacrylamide gel electrophoresis according to the procedure of Laemmli (41). Gels were stained with Coomassie Blue, destained, and exposed to Kodak XOMAT film for 24-36 h. For quantitative determination of the incorporated $\left[{ }^{32} \mathrm{P}\right]$-ADP-ribose the reaction was terminated by the addition of $400 \mu \mathrm{l}$ of a solution containing $2 \% \mathrm{SDS}(\mathrm{wt} / \mathrm{vol})$ and $1 \mathrm{mg} / \mathrm{ml} \mathrm{BSA}$ and precipitating the proteins with $500 \mu \mathrm{l}$ of $30 \%$ (wt/vol) TCA. Thereafter, the precipitated proteins were collected onto nitrocellulose filters. The filters were washed 10 times with $2 \mathrm{ml}$ of $6 \%$ TCA, placed in scintillation fluid and counted for retained radioactivity.

Measurement of actin filament content. F-Actin was measured as described by Wysolmerski and Lagunoff (15). Endothelial cells were grown in T25-tissue culture flasks, washed thrice with buffer $\mathrm{A}$ ( $\mathrm{pH} 7.2$, $75 \mathrm{mM} \mathrm{KCl}, 3 \mathrm{mM} \mathrm{MgSO}_{4}, 1 \mathrm{mM}$ EGTA, $0.2 \mathrm{mM}$ dithiothreitol, 10 $\mathrm{mM}$ imidazole, $10 \mu \mathrm{g} / \mathrm{ml}$ aprotinin, $0.1 \mathrm{mM}$ PMSF), and permeabilized with $0.03 \%$ saponin in puffer A for $10 \mathrm{~min}$ at room temperature. Cell monolayers were fixed in freshly prepared $3 \%$ formaldehyde in buffer $\mathrm{A}$ for $20 \mathrm{~min}$ at room temperature, washed, and stained in the dark with $0.175 \mu \mathrm{g} / \mathrm{ml}$ rhodamine phalloidin for $30 \mathrm{~min}$. After another wash extraction of rhodamine phalloidin was initiated by addition of ice cold HPLC-grade methanol and continued overnight at $-20^{\circ} \mathrm{C}$. Methanol extraction resulted in a quantitative removel of phalloidin bound to actin. Endothelial cells in methanol were removed from the flasks with a rubber policeman. The methanol suspension was aspirated, and centrifuged at $8,000 \mathrm{~g}$. The rhodamine in the supernatants was determined using an Aminco-Bowman spectrophotofluorometer (Colora, Lorch, FRG). Excitation and emission wavelengths were 542 and $563 \mathrm{~nm}$. Matched cell monolayers were washed with puffer A, lysed with $0.1 \%$ triton $\mathrm{X}-100$, scraped from the plate, and used for determination of protein according to Bradford (42). Data were expressed as nanograms phalloidin per microgram cell protein. F-Actin was removed from permeabilized endothelial cells by incubating.monolayers in $0.3 \mathrm{M} \mathrm{KI}$ overnight at $4^{\circ} \mathrm{C}$. After $\mathrm{KI}$ incubation monolayers were processed as outlined above. $\mathrm{KI}$ extraction resulted in a quantitative removal of endothelial actin.

Measurement of G-actin content. G-Actin was determined by the DNAse inhibition assay of Blikstad et al. (43) as described by Hinshaw et al. (44). $80 \mu \mathrm{g} / \mathrm{ml}$ calf thymus DNA was dissolved in $0.1 \mathrm{M}$ Tris- $\mathrm{HCl}$ (pH 7.5), $4 \mathrm{mM} \mathrm{MgSO}_{4}$, and $1.8 \mathrm{mM} \mathrm{CaCl}_{2}$ by gentle stirring at $4^{\circ} \mathrm{C}$ for $48 \mathrm{~h}$. DNAse 1 stock solution was prepared by adding $10 \mathrm{mg} / \mathrm{ml}$ DNAse to $0.125 \mathrm{M}$ Tris- $\mathrm{HCl}$ (pH 7.5), $5 \mathrm{mM} \mathrm{MgCl}, 2 \mathrm{mM} \mathrm{CaCl}_{2}, 1$ $\mathrm{mM} \mathrm{NaN}_{3}$, and $0.1 \mathrm{mM} \mathrm{PMSF}$. Working solutions were prepared by 100 -fold dilution in $20 \mathrm{mM}$ imidazole (pH 7.5), $30 \mathrm{mM} \mathrm{NaCl}$, and $15 \%$ glycerol. Toxin-treated endothelial cells in T-25 flasks were lysed in 500 $\mu$ l HBSS containing $1 \%$ triton X-100, $2 \mathrm{mM} \mathrm{MgCl}$, 2 mM EGTA, 0.2 mM ATP, $0.5 \mathrm{mM}$ DTT, and 0.1 mM PMSF (lysate solution). G-Actin was measured by mixing in a cuvette $10 \mu \mathrm{l}$ cell lysate and $10 \mu \mathrm{l}$ of DNAse solution to $3 \mathrm{ml}$ of DNA solution for $5 \mathrm{~s}$. Absorbance at $260 \mathrm{~nm}$ was determined immediately for $55 \mathrm{~s}$ in a Kontron-photometer and plotted by using the Kontron-enzyme-kinetic software. A standard curve for $30-70 \%$ inhibition of DNAse 1 was obtained by measuring the absorbance after addition of 0.1-2 $\mu \mathrm{g}$ bovine muscel actin. Data were expressed as \% G-actin of total cellular protein.

Visualization of F-actin. Because actin is concentrated along the margins of endothelial cells we used rhodamine-labeled phalloidin to visualize interendothelial gap formation. Monolayers were fixed at room temperature for $5 \mathrm{~min}$ at a hydrostatic pressure of $10 \mathrm{~cm} \mathrm{H}_{2} \mathrm{O}$ in HBSS (pH 7.4) containing $2 \%$ formaldehyde. After three washes with HBSS monolayers were permeabilized by exposure to acetone at $-20^{\circ} \mathrm{C}$ for $1 \mathrm{~min}$. Cells were then washed with HBSS and incubated for $30 \mathrm{~min}$ with rhodamine-labeled phalloidin $(1.4 \mu \mathrm{g} / \mathrm{ml})$. After a brief 
wash the preparations were mounted in $60 \%$ glycerol (containing $1.5 \%$ $n$-propyl gallate) and examined by fluorescence microscopy as previously described $(17,24)$.

Release of lactate dehydrogenase (LDH) was used as a marker of cytotoxicity. Endothelial cell monolayers grown on the polycarbonate filter membranes were exposed to the botulinum $\mathrm{C} 2$ toxin for $2 \mathrm{~h}$. The medium was removed and centrifuged with $8,000 \mathrm{~g}$ for $2 \mathrm{~min}$. LDH activity in the supernatant was determined by the colorimetric measurement of the reduction of sodium pyruvate in the presence of NADH (45). Enzyme release was expressed as the percentage of total enzyme activity released from endothelial cells in the presence of $100 \mu \mathrm{g} / \mathrm{ml}$ mellitin $(12,46)$.

Experimental protocol. In this study "sealed" endothelial cell monolayers were used, i.e., monolayers which showed a final filtration rate of $<20 \mu \mathrm{l} / \mathrm{min}$ and a membrane selectivity $>0.65$ at a hydrostatic pressure of $10 \mathrm{~cm} \mathrm{H}_{2} \mathrm{O}$. Control filters were stable throughout the experimental time (usually $2 \mathrm{~h}$ ). At the end of the experiments control cells always received $10 \mu \mathrm{g} / \mathrm{ml}$ staphylococcal alpha-toxin (12) to demonstrate the viability and reactivity of the cell monolayers studied.

Aliquots of $\mathrm{C} 2$ toxin (in buffer) or of CD (dissolved in DMSO, no independent effect of the solvent) were carefully added to the upper compartment (bolus addition). The injection procedure itself was without effect on the monolayer system as checked by frequent addition of stimulus-free buffer or solvent. In all experiments the components I and II of C2 toxin were added in a ratio of 1:1.

In some experiments the effects of a bolus addition of $\mathrm{CD}$ were compared to its continuous application. To study an interaction of both agents, we added submaximal concentrations of $C 2$ toxin and $C D$ simultaneously to the cell monolayers.

Phalloidin $\left(10^{-6}\right.$ and $\left.10^{-7} \mathrm{M}\right)$ or the solvent ethanol $(0.1$ and $0.01 \%)$ were added to cell monolayers on filter membranes in complete medium for $16 \mathrm{~h}$. During this period some phalloidin was taken up by endothelial cells as demonstrated by enhanced association of rhoda- mine-labeled phalloidin with cellular actin (not shown). Phalloidin-uptake by endothelial cells was very slow; preliminary studies indicated that an incubation period of 2 and $4 \mathrm{~h}$ was insufficient to load endothelial cells with phalloidin.

Statistical methods. Depending on the number of groups $(A)$ and the number of different time points studied $(B)$ data of Figs. 1, 2, 6-10 were analyzed by an $A \times B$ analysis of variance. Main effects were then compared by an $F$ probability test. When the analysis of variance had shown an interaction, individual data points were compared by Scheffe's test (47).

\section{Results}

Addition of components I and II (ratio 1:1) of botulinum C2 toxin to endothelial cell monolayers cultured on a polycarbonate filter membrane resulted in a dose-dependent (3-100 ng/ $\mathrm{ml}$ ) and time-dependent increase in the hydraulic conductivity of the cell monolayers (Fig. 1). Using $100 \mathrm{ng} / \mathrm{ml} \mathrm{C} 2$ toxin the effect was evident after $25-30 \mathrm{~min} ; 3 \mathrm{ng} / \mathrm{ml} \mathrm{C} 2$ toxin increased the permeability of endothelial monolayers after $\sim 90 \mathrm{~min}$. Control cell monolayers were stable throughout the experimental period and reacted appropriately upon addition of staphylococcal alpha-toxin (Fig. 1) (12).

Both components of the $\mathrm{C} 2$ toxin had to be present to induce the increase in endothelial permeability. Addition of 100 $\mathrm{ng} / \mathrm{ml}$ of toxin component I only or of $100 \mathrm{ng} / \mathrm{ml}$ of toxin component II only was without effect on endothelial permeability (data not shown).

Botulinum C2 toxin did not injure endothelial cells; i.e., there was no enhanced release of LDH from toxin-exposed endothelial cells (data not shown). In contrast to cytochalasin

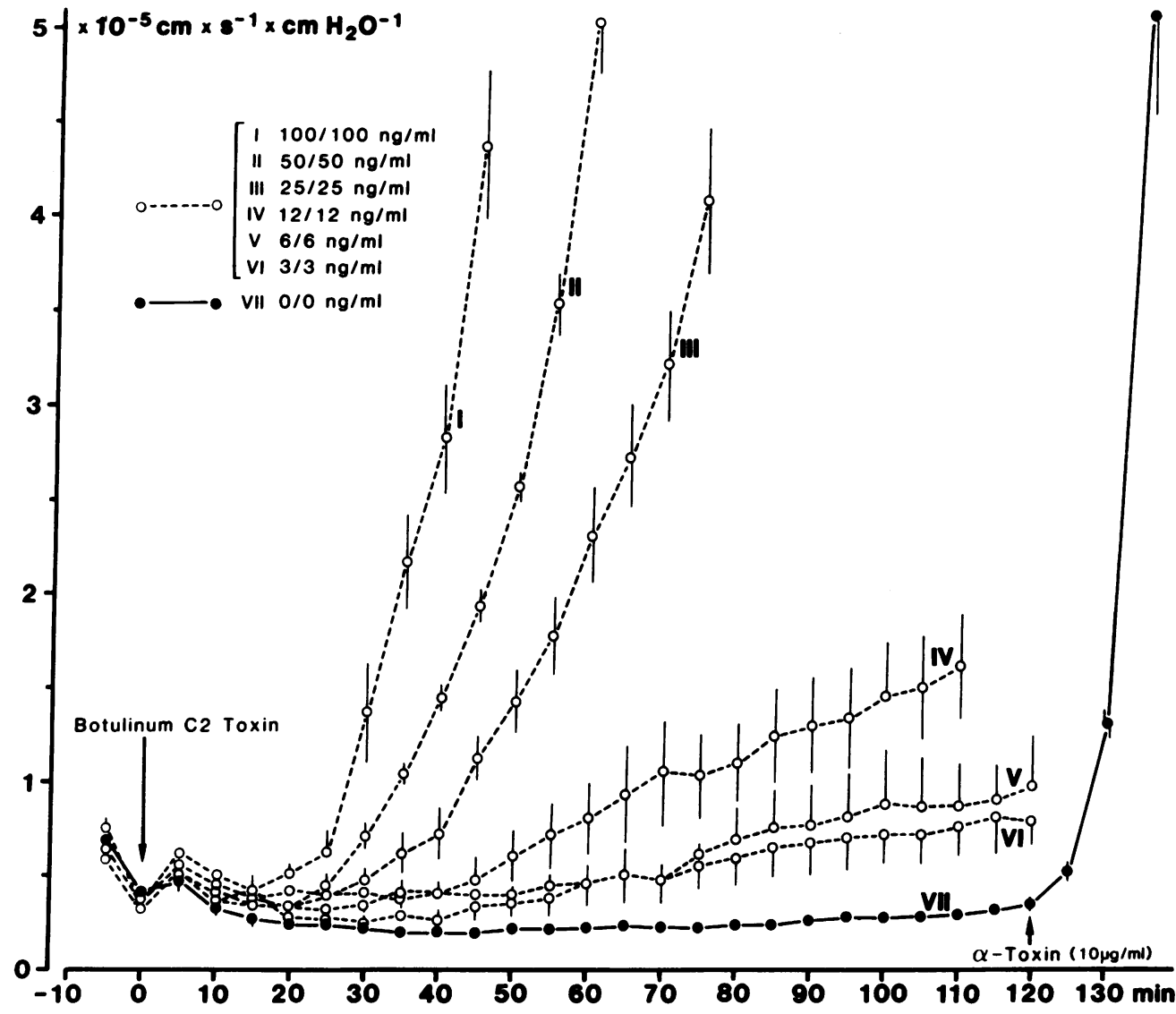

Figure 1. Dose- and time-dependent increase in hydraulic conductivity of endothelial cell monolayer by botulinum $\mathrm{C} 2$ toxin. Components I and II of $\mathrm{C} 2$ toxin were added in equal amounts. Even the lowest toxin concentration tested $(3 \mathrm{ng} / \mathrm{ml})$ significantly increased the water filtration rate across the monolayer. Control monolayers were stable throughout the experimental period and responded promptly upon addition of staphylococcal alpha-toxin. Data presented are mean $\pm \mathrm{SE}$ of seven separate experiments. 


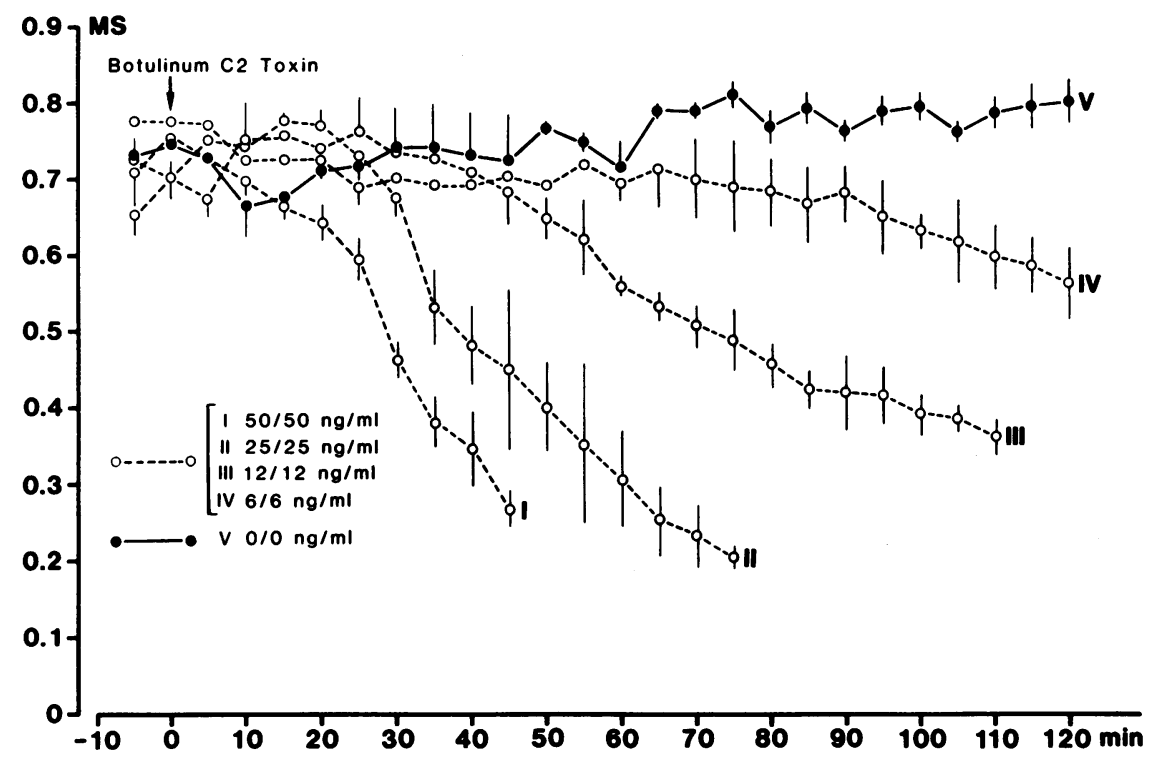

Figure 2. Dose- and time-dependent decrease of the selectivity of endothelial cell monolayers by botulinum $\mathrm{C} 2$ toxin. Hydraulic conductivity (Fig. 1) and selectivity (see Methods for experimental details) were determined simultaneously on the same endothelial cell monolayer.

$\mathrm{D}$ (see later) the effects of $\mathrm{C} 2$ toxin were not reversible within $2 \mathrm{~h}$.

Botulinum $\mathrm{C} 2$ toxin also dose-dependently altered the selectivity of endothelial cell monolayers (Fig. 2). In control monolayers this parameter was stable at $\sim 0.7$ throughout the entire experimental period. It dropped from 0.7 to 0.2 in the presence of $50 \mathrm{ng} / \mathrm{ml} \mathrm{C} 2$ toxin, i.e., the endothelial cell monolayer lost its permselectivity. Lower $\mathrm{C} 2$ concentrations had intermediate effects on the selectivity of the cell monolayers (Fig. 2). Hydraulic conductivity (Fig. 1) and selectivity (Fig. 2) were determined on the same endothelial cell monolayers.

Staining of the endothelial actin filament with rhodaminelabeled phalloidin showed formation of gaps between endothelial cells after exposure to $50 \mathrm{ng} / \mathrm{ml} \mathrm{C} 2$ toxin for $60 \mathrm{~min}$ (Fig. 3).

The $\mathrm{C} 2$ toxin-induced alteration of endothelial monolayer permeability was paralleled by an ADP-ribosylation of endothe-
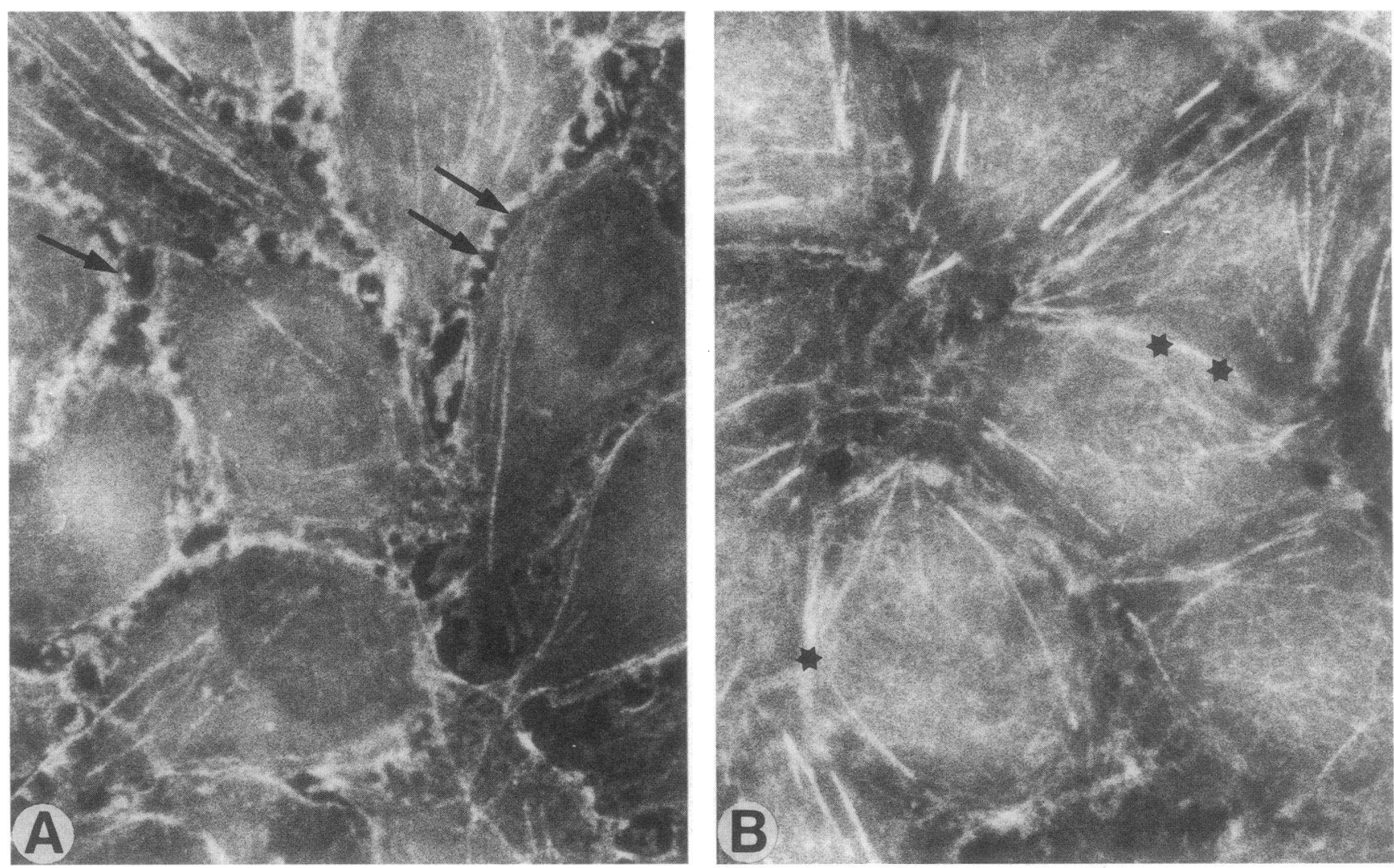

Figure 3. Visualization of interendothelial gaps after staining of endothelial actin filaments with rhodamine-labeled phalloidin. $(A)$ Formation of interendothelial gaps (arrows) is noted in endothelial cell monolayers exposed to $50 \mathrm{ng} / \mathrm{ml}$ botulinum C2 toxin for 60 min, while (B) no gaps are seen in control monolayers $(*), \times 130)$. 


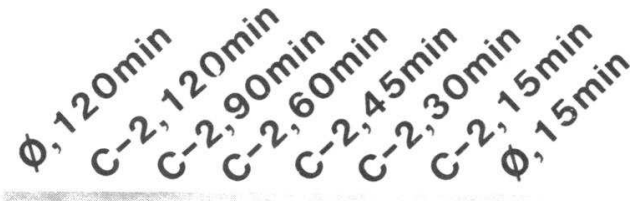

$43 \mathrm{kD} \rightarrow=-\cdots$

\section{Front $\rightarrow$}

Figure 4. Time-dependent increase in ADP-ribosylation of G-actin $(43 \mathrm{kD})$ in endothelial cell monolayers exposed to botulinum $\mathrm{C} 2$ toxin. Endothelial cells were exposed to $25 \mathrm{ng} / \mathrm{ml} \mathrm{C} 2$ toxin for the indicated periods of time. Cells were then washed and lysed, and the lysates were ADP-ribosylated with $1 \mu \mathrm{g} / \mathrm{ml}$ component I of $\mathrm{C} 2$ toxin in the presence of $5 \mu \mathrm{Ci}\left[{ }^{32} \mathrm{P}\right] N A D$ as outlined in Methods. Radioactively labeled proteins were analyzed by SDS-PAGE and an example of the autoradiograms of the gels is shown.

lial actin which was determined in cell lysates by the reduction of a second C2I toxin-induced ADP-ribosylation of actin with $\left.{ }^{32} \mathrm{P}\right]-N A D$. The autoradiogram in Fig. 4 illustrates that in endothelial lysates only one protein with $43 \mathrm{kD}$, corresponding to G-actin, was ADP-ribosylated by $\mathrm{C} 2$ toxin. ADP-ribosylation of endothelial actin occurred in a time and concentration dependent manner (Figs. 4, 5). As shown in Fig. 1, treatment of endothelial cells with $25 \mathrm{ng} / \mathrm{ml} \mathrm{C} 2$ toxin for 30 min elicited a

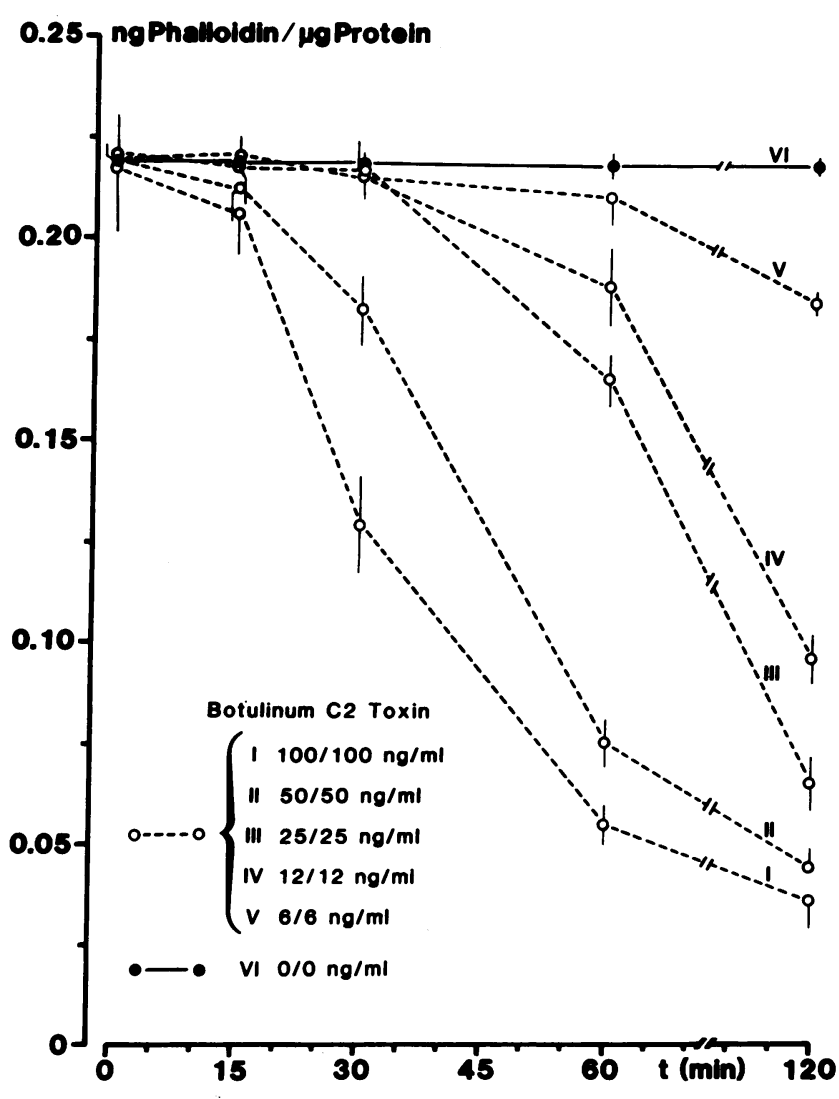

Figure 6. Time- and dose-dependent decrease in endothelial F-actin content by botulinum $\mathrm{C} 2$ toxin. This parameter was determined by quantitating actin-bound rhodamine phalloidin as outlined in Methods. Data presented are mean $\pm \mathrm{SE}$ of seven separate experiments.
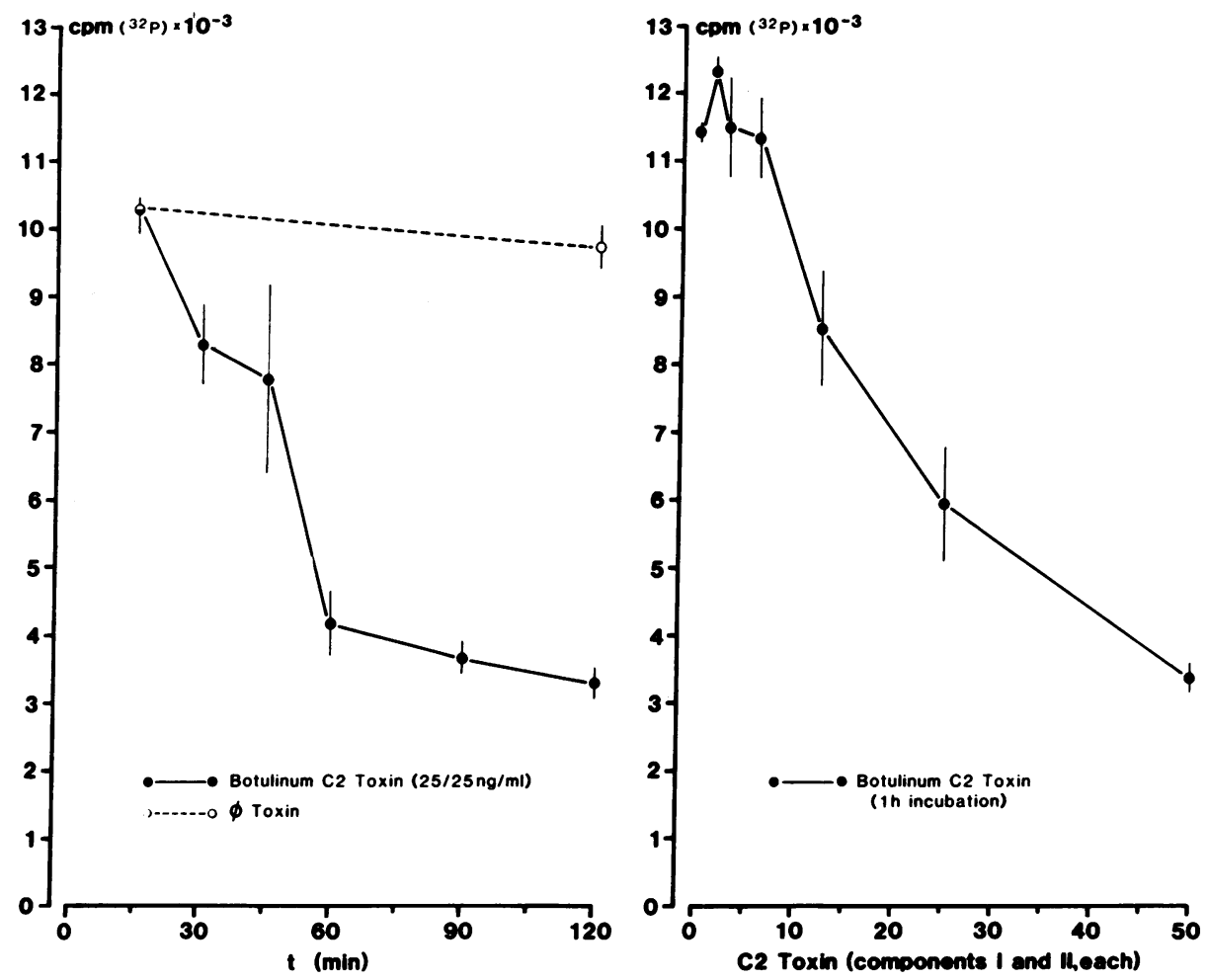

Figure 5. Time-dependent (left) and dose-dependent $(r i g h t)$ increase in ADP-ribosylation of G-actin $(43 \mathrm{kD})$ in endothelial cell monolayers exposed to botulinum $\mathrm{C} 2$ toxin. Cells were treated with $25 \mathrm{ng} / \mathrm{ml} \mathrm{C} 2$ toxin for the indicated periods of time (left) or for $1 \mathrm{~h}$ with the indicated concentrations of $\mathrm{C} 2$ toxin (right). For details see legend of Fig. 3. Data presented are mean $\pm S E$ of three separate experiments. 
significant increase in permeability. After this period of time $\sim 20 \%$ of the modifiable actin was ADP-ribosylated by the toxin (Fig. $5 \mathrm{~A}$ ). Studies on the concentration dependency of $\mathrm{C} 2$ toxin-induced ADP-ribosylation revealed that in endothelial cells $12 \mathrm{ng} / \mathrm{ml}$ of $\mathrm{C} 2$ toxin was the lowest concentration to induce a significant ADP-ribosylation of actin after $1 \mathrm{~h}$ (Fig. 5 $B$ ). Identical toxin concentrations were necessary for a significant increase in endothelial permeability (Fig. 1).

In endothelial cell monolayers botulinum $\mathrm{C} 2$ toxin induced a dose- and time-dependent increase in G-actin content (Fig. 6) and decrease in F-actin content (Fig. 7). As shown in Fig. 1, for a 60 -min incubation $12 \mathrm{ng} / \mathrm{ml} \mathrm{C} 2$ toxin was the lowest concentration to increase endothelial permeability. After this period of time G-actin content had increased by $\sim 15 \%$. At the same time F-actin content had decreased to a similar extent.

Next we examined the effects of $\mathrm{C} 2$ toxin on endothelial permeability in the presence of an agent which stabilizes F-actin, i.e., phalloidin which decreases the rate of actin depolymerization $(48,49)$. Endothelial cell monolayers were incubated with $10^{-6}$ and $10^{-7} \mathrm{M}$ phalloidin overnight, washed several times, and mounted into the chambers. In phalloidin-pretreated cell monolayers the increase in endothelial permeability following C2 toxin was reduced by $90 \%$ (Fig. 8). Phalloidin at the concentrations used was not toxic to endothelial cells as

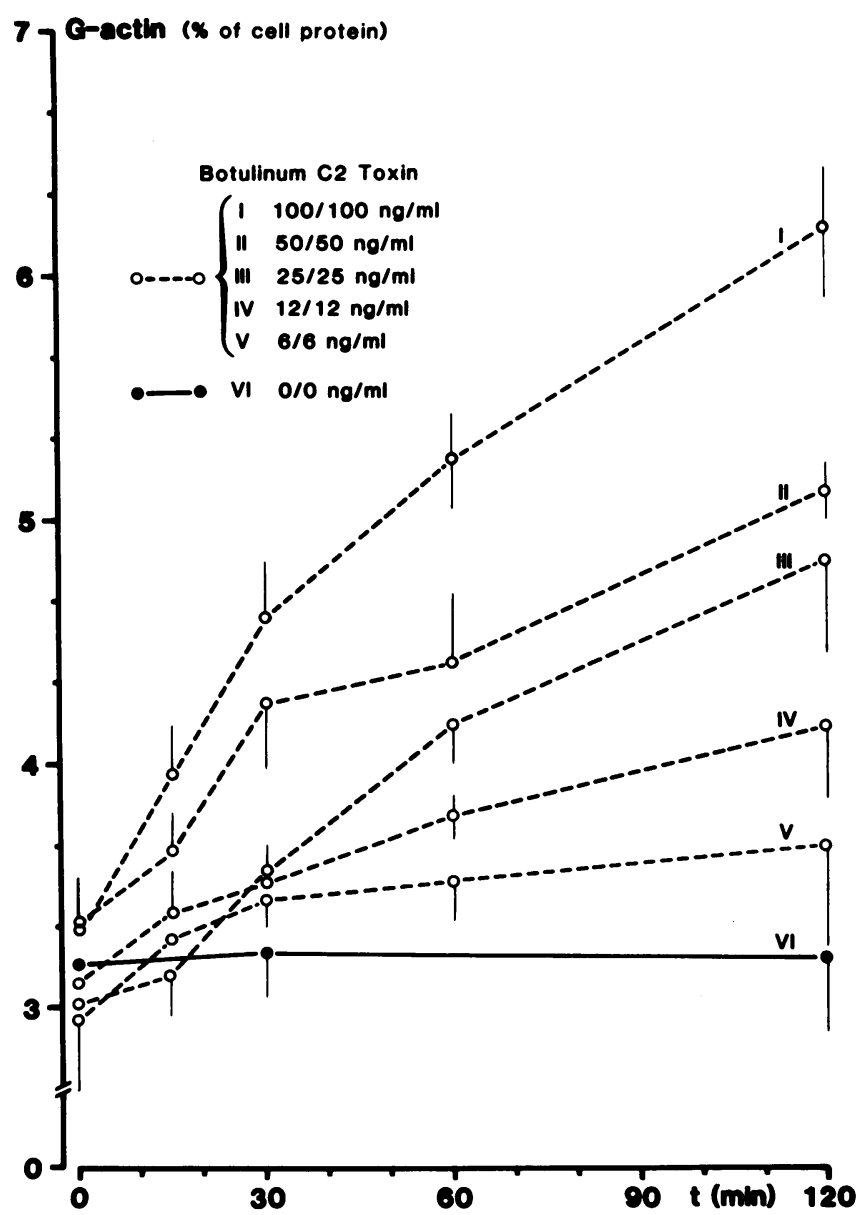

Figure 7. Time- and dose-dependent increase in endothelial G-actin content by botulinum $\mathrm{C} 2$ toxin. This parameter was determined using the DNAse inhibition assay as outlined in Methods. Data presented are mean $\pm \mathrm{SE}$ of four separate experiments.

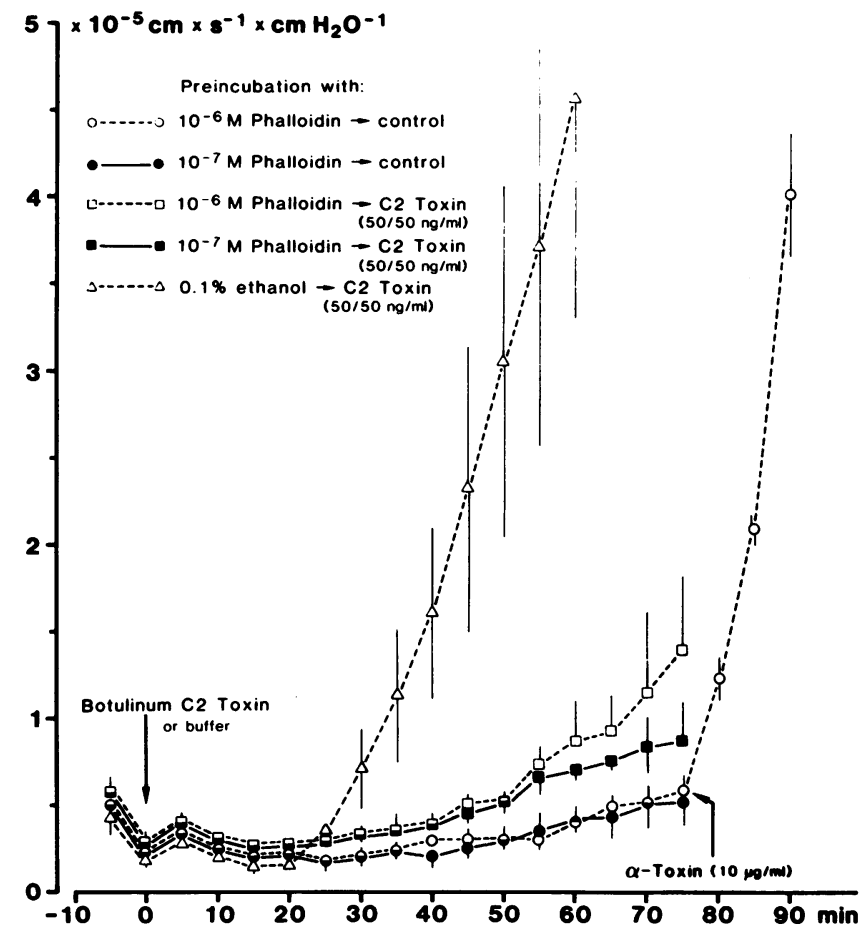

Figure 8. Reduction of the $\mathrm{C} 2$ toxin-induced increase in the hydraulic conductivity of endothelial monolayers by pretreatment of cells with $10^{-6}$ and $10^{-7} \mathrm{M}$ phalloidin for $16 \mathrm{~h}$. Phalloidin pretreatment, however, did not impair the effect of staphylococcal alpha-toxin. Different groups were studied simultaneously. Data presented are mean $\pm \mathrm{SE}$ of six separate experiments.

indicated by no enhanced LDH-release (not shown). In addition, phalloidin-pretreated monolayers showed a normal basal permeability and reacted promptly upon addition of staphylococcal alpha-toxin (Fig. 8) (12). Moreover, phalloidin pretreatment did not reduce $\mathrm{C} 2$ toxin-related ADP-ribosylation: incorporated $\left[{ }^{32} \mathrm{P}\right]$-ADP-ribose in endothelial cells exposed to 0,25 / $25 \mathrm{ng} / \mathrm{ml}$, and $50 / 50 \mathrm{ng} / \mathrm{ml} \mathrm{C} 2$ toxin were $11,400 \pm 763$, $6,150 \pm 325$, and $3,290 \pm 290 \mathrm{cpm}$; the corresponding data for phalloidin-treated cells were $10,820 \pm 490,5,750 \pm 473$, and $3,660 \pm 140 \mathrm{cpm}$ (mean $\pm \mathrm{SE}, n=3$ ).

We then compared the effects of $\mathrm{C} 2$ toxin with those of cytochalasin D (CD), ${ }^{1}$ an agent which caps barbed ends of actin filaments and presumably possesses filament severing activity (50-53). Bolus addition of CD in the range of $0.5-1.0 \mu \mathrm{g} / \mathrm{ml}$ dose-dependently increased the hydraulic conductivity of endothelial cell monolayers. The CD effect peaked at $10 \mathrm{~min}$ and then steadily declined within 60-90 min (Fig. $9 \mathrm{~A}$ ). Thus, in contrast to $\mathrm{C} 2$ toxin, the effects of $\mathrm{CD}$ appeared to be reversible. To study this aspect in more detail, a bolus addition of CD was compared to a continuous application $(a)$ and the effects of $\mathrm{CD}$ were studied in an on-off-on-fashion (b) (Fig. $9 \mathrm{~B})$ : $(a) \mathrm{A}$ continuous application of $C D$, thus maintaining $0.75 \mu \mathrm{g} / \mathrm{ml}$ $\mathrm{CD}$ in the upper compartment of the filter system, induced a rapid and large increase in the permeability of the endothelial monolayers which was higher and which did not decline as compared to a bolus addition of $0.75 \mu \mathrm{g} / \mathrm{ml} \mathrm{CD}$. (b) Changing

1. Abbreviation used in this paper: $\mathrm{CD}$, cytochalasin $\mathrm{D}$. 


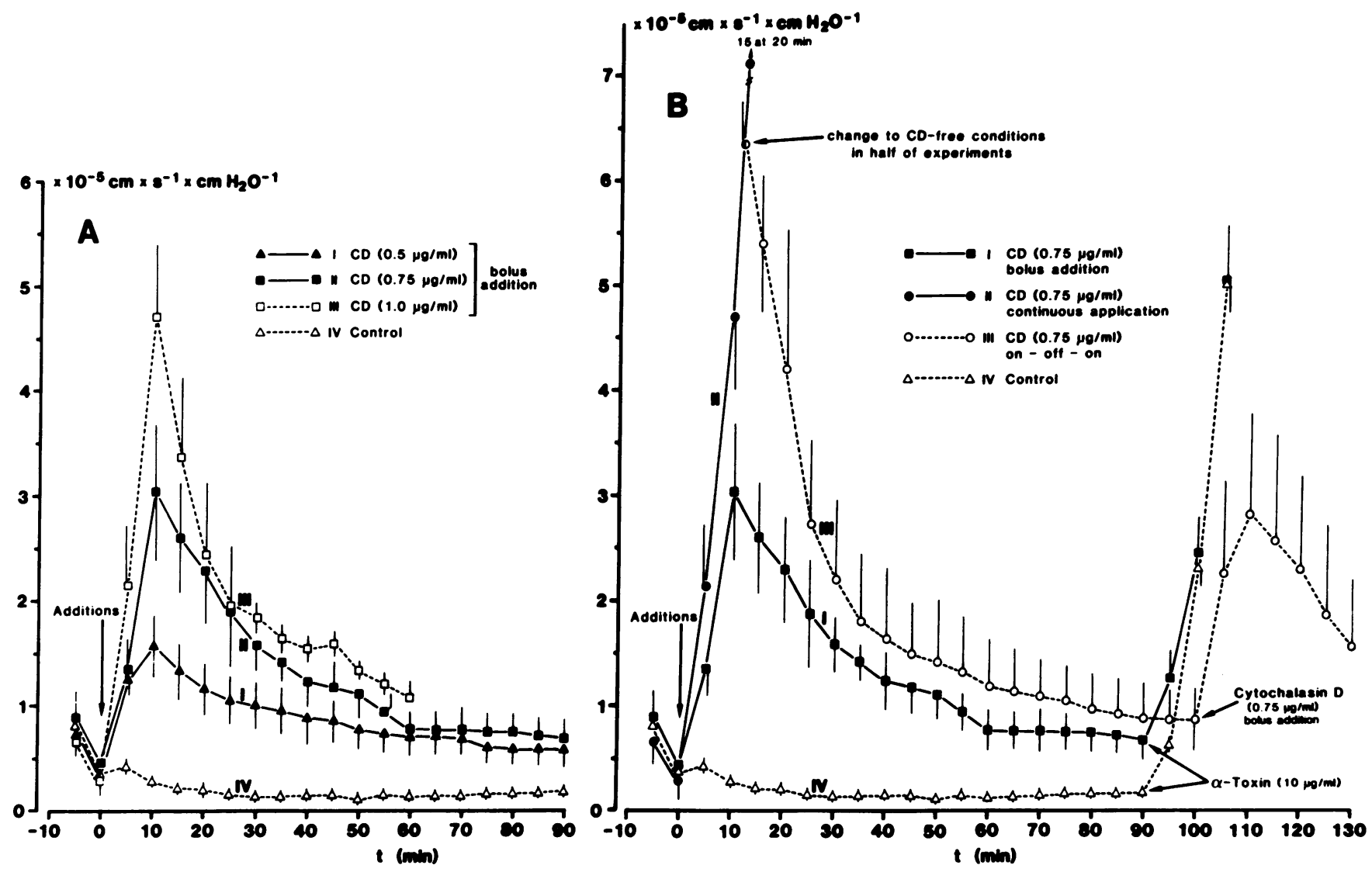

Figure 9. Influence of cytochalasin $\mathrm{D}(C D)$ on the hydraulic conductivity of endothelial cell monolayers: $(A)$ Dose-dependent reversible increase in endothelial permeability upon bolus addition of cytochalasin $\mathrm{D}(C D)$ at time point 0 . Data presented are mean \pm SE of six separate experiments. $(B)$ Comparison of continuous versus bolus application of $C D$. Upon addition of $C D$ as a bolus the increased permeability peaked at 10 min and then steadily declined (I). A continuous application of CD resulted in a large and continuous increase in endothelial permeability (II). Change to CD-free conditions reversed the effect (III). Readdition of CD raised again endothelial permeability. Staphylococcal alpha-toxin rapidly increased endothelial permeability in control cells and cells previously exposed to CD. Data presented are mean $\pm S E$ of four separate experiments.

the fluid in the upper compartment to CD-free conditions reversed the $C D$-induced increased endothelial permeability; readdition of $0.75 \mu \mathrm{g} / \mathrm{ml} \mathrm{CD}$ restored the effect again (Fig. $9 B$ ).

Additional studies showed a rapid decrease in endothelial F-actin content after continuous exposure to $0,0.5,0.75$, and $1.0 \mu \mathrm{g} / \mathrm{ml} \mathrm{CD}$. After $2 \mathrm{~min} \mathrm{~F}$-actin content (indicated as nanograms phalloidin/milligram protein) dropped from $265 \pm 3$ to $257 \pm 5,245 \pm 5$, and $217 \pm 4$ (mean \pm SE, $n=7$ ).

Finally, the combined effects of submaximal concentrations of $\mathrm{C} 2$ toxin and $\mathrm{CD}$ on endothelial monolayer permeability were studied. $12.5 \mathrm{ng} / \mathrm{ml} \mathrm{C2}$ toxin alone and $0.5 \mu \mathrm{g} / \mathrm{ml} \mathrm{CD}$ alone had moderate effects on the permeability of the endothelial monolayer. Addition of both agents $(12.5 \mathrm{ng} / \mathrm{ml} \mathrm{C} 2$ toxin, $0.5 \mu \mathrm{g} / \mathrm{ml} \mathrm{CD}$ ) resulted in a synergistic increase of endothelial permeability (Fig. 10). Interestingly, the kinetics of each agent were preserved. There was, however, a merely additive effect of both agents on endothelial F-actin content (data not shown).

\section{Discussion}

This study demonstrates that botulinum $\mathrm{C} 2$ toxin which ADPribosylates actin, causes an increase in the permeability of endothelial cell monolayers derived from porcine pulmonary arteries. With the highest toxin concentration used $(100 \mathrm{ng} / \mathrm{ml})$ the hydraulic conductivity increased 10 -fold. In addition, the cell monolayer lost its permselectivity as indicated by the large drop of the index of selectivity from 0.7 to 0.2 . Even $3 \mathrm{ng} / \mathrm{ml}$ toxin significantly increased endothelial permeability within 2 $h$. The changes in permeability were accompanied by formation of intercellular gaps between endothelial cells thereby possibly opening a paracellular pathway for enhanced fluid exchange. C2 toxin-induced enhancement of endothelial monolayer permeability occurred in the absence of overt cell damage and was not reversible within $2 \mathrm{~h}$.

In this study endothelial permeability was investigated on "sealed" endothelial cell monolayers in the presence of a welldefined transendothelial pressure gradient. Previously we have shown that application of a continuous hydrostatic pressure resulted in a "sealing" of endothelial cell monolayers, i.e., within 1-2 $\mathrm{h}$ the hydraulic conductivity decreased and the permselectivity increased $(12,46)$. We believe that this procedure, as compared to studies done under strict diffusion conditions, will allow a better simulation of the in vivo situation.

The effects of $\mathrm{C} 2$ toxin on endothelial permeability were accompanied by an increased ADP-ribosylation of endothelial G-actin. Recently it was demonstrated that $\mathrm{C} 2$ toxin-induced ADP-ribosylation of G-actin causes depolymerization of F-actin and an increase in the G-actin pool $(30,54)$. Assuming that 


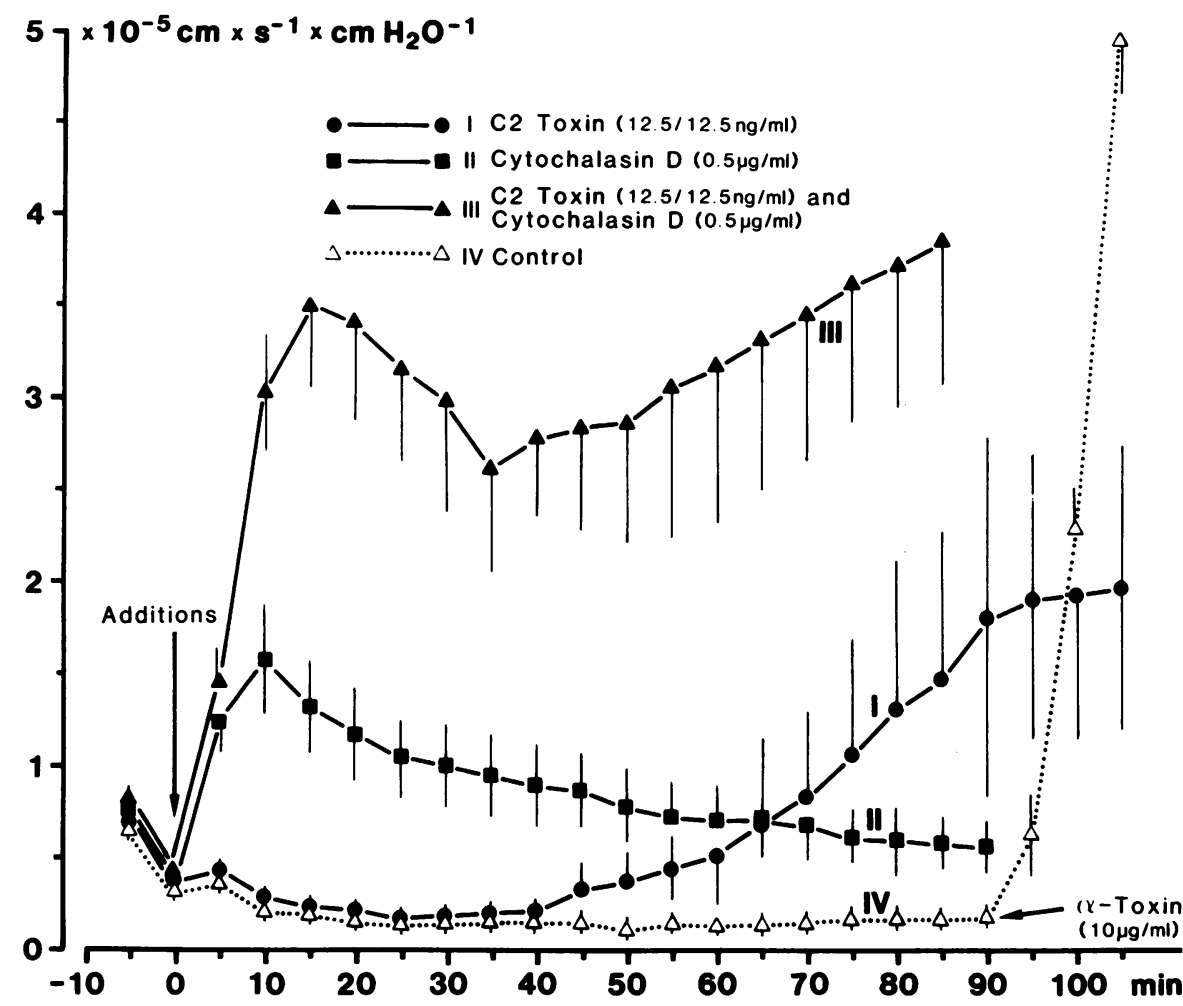

Figure 10. Synergistic effect of CD and C2 toxin on endothelial permeability. Submaximal concentrations of $\mathrm{CD}(0.5 \mu \mathrm{g} / \mathrm{ml})$ or $\mathrm{C} 2$ toxin $(12.5 \mathrm{ng} / \mathrm{ml})$ had a moderate effect on the permeability of an endothelial cell monolayer while a combination of both markedly increased it. Experiments were performed simultaneously. Data presented are mean \pm SE of six separate experiments.

in resting endothelial cells a dynamic equilibrium exits between polymerized and nonpolymerized actin botulinum $\mathrm{C} 2$ toxin alters this balance in favour of increased actin depolymerization. This point was proven experimentally in the present study by quantitating F- and G-actin content. G-Actin increased and $\mathrm{F}$-actin decreased in $\mathrm{C} 2$ toxin-treated endothelial cells in a time- and dose-dependent manner. Because ADP-ribosylated actin lost its ability to polymerize $\mathrm{C} 2$ toxin-induced ADP-ribosylation reduces the effective concentration of the actin monomer pool participating in filament growth (33). Moreover, toxin-modified actin acts like a capping protein thereby preventing further addition of G-actin to the growing end of F-actin (32). In contrast, ADP-ribosylation of actin does not block or reduce depolymerization at the pointed end of actin filaments.

The notion that $\mathrm{C} 2$ toxin-induced actin depolymerization was involved in enhanced endothelial permeability was supported by studies using phalloidin. This agent binds tightly to polymerized actin and shifts the equilibrium between actin filaments and actin monomers towards filament formation largely by decreasing the rate of the actin depolymerization $(48,49)$. The $\mathrm{C} 2$ toxin-induced increase in endothelial permeability was substantially reduced in phalloidin-loaded cell monolayers suggesting that phalloidin prevents the $\mathrm{C} 2$ toxin-induced imbalance between actin polymerization and depolymerization.

Phalloidin does not readily permeate cell membranes and its uptake in cells (with the exception of hepatocytes) probably proceeds by pinocytosis $(50)$. In the present study endothelial cells had to be incubated with phalloidin for at least $16 \mathrm{~h}$ in order to obtain a phalloidin-loading which was sufficiently high to block the effects of $\mathrm{C} 2$ toxin. In addition, after $16 \mathrm{~h}$ an increased staining of cells with rhodamine-labeled phalloidin was noted by immunofluorescence. A recent study showed that phalloidin reduced the histamine- and bradykinin-induced in- crease in permeability of bovine aortic endothelial cells (55), supporting the view that phalloidin can enter endothelial cells.

It is of interest that phalloidin pretreatment did not block the increase in the permeability of endothelial cell monolayers by staphylococcal alpha-toxin. Exposure of endothelial cells to staphylococcal alpha-toxin, a channel forming protein (56), will increase intracellular free $\mathrm{Ca}^{2+}$. Recently, we have hypothesized that this may trigger an interaction between actin and myosin which finally would result in an active retraction of cells with subsequent formation of intercellular gaps $(12,24)$. Based on these data it is conceivable that phalloidin pretreatment did not impair the endothelial response to staphylococcal alpha-toxin.

Another aspect of interest is that in the present study phalloidin pretreatment did not reduce the permeability of resting endothelial monolayers. This is in contrast to Alexander et al. (55) who noted a decreased basal endothelial permeability in phalloidin-treated cells. In the present study resting cells probably had already optimized their barrier function which could not be further improved by increasing F-actin.

Studies using $\mathrm{CD}$ were performed to corroborate the notion that the microfilament system is important for regulating endothelial monolayer permeability. The most prominent effect of $\mathrm{CD}$ is its capping function, i.e., its reversible binding to the barbed end of actin filaments; in addition, CD reportedly severs F-actin (50-53). In our system CD caused a dose-dependent increase in endothelial permeability which was readily reversible upon changing to $\mathrm{CD}$-free conditions and which could be reproduced several times within the same cell monolayer. These studies confirm and extend experiments by Shasby et al. (26).

All these data presented can be interpreted to indicate that an intact endothelial microfilament system is important for maintaining a functionally competent endothelial barrier. It is 
not clear, however, how ADP-ribosylation of G-actin and depolymerization of actin result in increased permeability of endothelial cell monolayers. It should be emphasized that the permeability of an endothelial monolayer is most likely not simply governed by the ratio of F- to G-actin pools. Several observations presented herein (a small decrease/increase in F-/G-actin content altered endothelial permeability; studies combining $\mathrm{CD}$ and $\mathrm{C} 2$ toxin) suggest that polymerization/depolymerization of selective actin pools are involved in the regulation of endothelial permeability. For epithelium, for example, it is known that the microfilament system is associated with tight junctional proteins (57-59). If the same is true for endothelium actin disassembly may have a disorganizing effect on intercellular junctions which in turn may result in the observed cell retraction with subsequent gap formation and enhanced paracellular flux of water and albumin. Thus, the quantitation of the contributions made by selective actin pools (dense peripheral band, central microfilaments, plasma membrane-associated microfilaments) will be of considerable interest.

The interpretation of the data presented is limited especially because the studies were performed on cultured porcine pulmonary artery endothelial cells. For technical reasons it is currently not possible to examine human pulmonary microvascular endothelial cells. Therefore, the applicability of the data presented to the human pulmonary microcirculation is not clear.

The previous evidence for the hypothesis that the cellular microfilament system is involved in the regulation of endothelial permeability was primarily based on alterations of the distribution of F-actin and on studies using cytochalasins, reagents with questionable specificity (50). The findings presented indicate that the specific actin tool botulinum $\mathrm{C} 2$ toxin and the controlled endothelial cell monolayer model are apparently useful to elucidate the role of cytoskeletal components for the regulation of vascular permeability.

\section{Acknowledgments}

The technical assistance of S. Tannert-Otto and P. Röhrig is greatly appreciated. We thank P. Müller for skillful graphic illustrations.

This work was supported by the Deutsche Forschungsgemeinschaft (SFB 249)

Parts of this work will be included in the M.D. thesis of M. Polley and J. Seybold.

\section{References}

1. Rinaldo, J. E., and R. M. Rogers. 1982. Adult respiratory-distress syndrome. Changing concepts of lung injury and repair. N. Engl. J. Med. 306:900909.

2. Majno, G., S. M. Shea, and M. Leventhal. 1969. Endothelial contraction induced by histamine-type mediators. J. Cell Biol. 42:647-672.

3. Joris, I., G. Majno, E. J. Corey, and R. A. Lewis. 1987. The mechanism of vascular leakage induced by leukotriene $\mathrm{E}_{4}$ : endothelial contraction. $\mathrm{Am}$. $\mathrm{J}$. Pathol. 126:19-24.

4. Meyrick, B. O., U. S. Ryan, and K. L. Brigham. 1986. Direct effects of $E$. coli endotoxin on structure and permeability of pulmonary endothelial monolayers and the endothelial layer of intimal explants. Am. J. Pathol. 122:140-151.

5. Killackey, J. J. F., M. G. Johnston, and H. Z. Movat. 1986. Increased permeability of microcarrier-cultured endothelial monolayers in response to histamine and thrombin. Am. J. Pathol. 122:50-61.

6. Phillips, P. G., and M. Tsan. 1988. Hyperoxia causes increased albumin permeability of cultured endothelial monolayers. J. Appl. Physiol. 64:1 196-1202.

7. Friedman, M., U. S. Ryan, W. C. Davenport, E. L. Chaney, D. L. Strickland, and L. Kwock. 1986. Reversible alterations in cultured pulmonary artery endothelial cell monolayer morphology and albumin permeability induced by ionizing radiation. J. Cell. Physiol. 129:237-249.
8. Shasby, D. M., S. E. Lind, S. S. Shasby, J. C. Goldsmith, and G. W. Hunninghake. 1985. Reversible oxidant-induced increases in albumin transfer across cultured endothelium: alterations in cell shape and calcium homeostasis. Blood. 65:605-614.

9. Garcia, J. G. N., A. Silfinger-Birnboim, R. Bizios, P. J. Del Veccio, J. W. Fenton II, and A. B. Malik. 1986. Thrombin-induced increase in albumin permeability across the endothelium. J. Cell. Physiol. 128:96-104.

10. Bussolino, F., G. Camussi, M. Aglietta, P. Braquet, A. Bosia, G. Pescarmona, F. Sanavio, N. D'urso, and P. C. Marchisio. 1987. Human endothelial cells are targets for platelet-activating factor: platelet-activating factor induces changes in cytoskeleton structures. J. Immunol. 139:2439-2446.

11. Shasby, D. M., S. S. Shasby, and M. J. Peach. 1983. Granulocytes and phorbol myristate acetate increase permeability to albumin of cultured endothelial monolayers and isolated perfused lungs. Am. Rev. Respir. Dis. 127:72-76.

12. Suttorp, N., T. Hessz, W. Seeger, A. Wilcke, R. Koob, F. Lutz, and D. Drenckhahn. 1988. Bacterial exotoxins and endothelial permeability for water and albumin in vitro. Am. J. Physiol. 255:C368-C376.

13. Malik, A. B., W. M. Selig, and K. E. Burhop. 1985. Cellular and humoral mediators of pulmonary edema. Lung. 163:193-219.

14. Rotrosen, D., and J. I. Gallin. 1986. Histamine type I receptor occupancy increases endothelial cytosolic calcium, reduces F-actin, and promotes albumin diffusion across cultured endothelial monolayers. J. Cell Biol. 103:2379-2387.

15. Wysolmerski, R. B., and D. Lagunoff. 1988. Inhibition of endothelial cell retraction by ATP depletion. Am. J. Pathol. 132:28-37.

16. Wysolmerski, R. B., and D. Lagunoff. 1985. The effect of ethchlorvynol on cultured endothelial cells. Am. J. Pathol. 119:505-512.

17. Drenckhahn, D., and J. Wagner. 1986. Stress fibers in the splenic sinus endothelium in situ: molecular structure, relationship to the extracellular matrix, and contractility. J. Cell Biol. 102:1738-1747.

18. Drenckhahn, D. 1983. Cell motility and cytoplasmatic filaments in vascular endothelium. Prog. Appl. Microcirc. 1:53-70.

19. Wong M. K. K., and A. I. Gotlieb. 1986. Endothelial cell monolayer integrity. I. Characterization of dense peripheral band of microfilaments. Arteriosclerosis. 6:212-219.

20. Wong, A. J., T. D. Pollard, and I. M. Herman. 1983. Actin filament stress fibers in vascular endothelial cells in vivo. Science (Wash. DC). 219:867-869.

21. Franke, R.-P., M. Gräfe, H. Schnittler, D. Seiffge, C. Mittermayer, and D. Drenckhahn. 1984. Induction of human vascular endothelial stress fibers by fluid shear stress. Nature (Lond.). 307:648-649.

22. Heltianu, C., I. Bogdan, E. Constantinescu, and M. Simionescu. 1986. Endothelial cells express a spectrin-like cytoskeletal protein. Circ. Res. 58:605610 .

23. Pratt, B. M., A. S. Harris, J. S. Morrow, and J. A. Madri. 1984. Mechanisms of cytoskeletal regulation: modulation of aortic endothelial cell spectrin by the extracellular matrix. Am. J. Pathol. 117:349-354.

24. Schnittler, H. J., A. Wilke, T. Gress, N. Suttorp, and D. Drenckhahn. 1990. Role of actin and myosin in the control of paracellular permeability in pig, rat, and human vascular endothelium. J. Physiol. (Lond.). 431:379-401.

25. Wysolmerski, R. B and D. Lagunoff. 1990. Involvement of myosin lightchain kinase in endothelial cell retraction. Proc. Natl. Acad. Sci. USA. 87:16-20.

26. Shasby, D. M., S. S. Shasby, J. M. Sullivan, and M. J. Peach. 1982. Role of endothelial cell cytoskeleton in control of endothelial permeability. Circ. Res. 51:657-661.

27. Aktories, K., M. Bärmann, I. Ohishi, S. Tsuyama, K. H. Jakobs, and E. Habermann. 1986. Botulinum C2 toxin ADP-ribosylates actin. Nature (Lond.) 322:390-392.

28. Ohishi, I., M. Iwasaki, and G. Sakaguchi. 1980. Purification and characterization of two components of botulinum C2 toxin. Infect. Immun. 30:668-673.

29. Aktories, K., T. Ankenbauer, B. Schering, and K. H. Jakobs. 1986. ADPribosylation of platelet actin by botulinm C2 toxin. Eur. J. Biochem. 161:155162.

30. Reuner, K. H., P. Presek, C. B. Boschek, and K. Aktories. 1987. Botulinum $\mathrm{C} 2$ toxin ADP-ribosylates actin and disorganizes the microfilament network in intact cells. Eur. J. Cell Biol. 43:134-140.

31. Vandekerckhove, J., B. Schering, M. Bärmann, and K. Aktories. 1988. Botulinum C2 toxin ADP-ribosylates cytoplasmatic beta/gamma-actin in arginine 177. J. Biol. Chem. 263:696-700.

32. Wegner, A., and K. Aktories. 1988. ADP-ribosylated actin caps the barbed ends of actin filaments. J. Biol. Chem. 263:13739-13742.

33. Aktories, K., and A. Wegner. 1989. ADP-ribosylation of actin by clostridial toxins. J. Cell Biol. 109:1385-1387.

34. Suttorp, N., and L. M. Simon. 1982. Lung cell oxidant injury. Enhancement of polymorphonuclear leukocyte-mediated cytotoxicity in lung cells exposed to sustained in vitro hyperoxia. J. Clin. Invest. 70:342-350.

35. Suttorp, N., W. Seeger, E. Dewein, S. Bhakdi, and L. Roka. 1985. Staphylococcal alpha-toxin induced $\mathrm{PGI}_{2}$ production in endothelial cells: role of calcium. Am. J. Physiol. 248:C127-C134.

36. Suttorp, N., C. Galanos, and H. Neuhof. 1987. Endotoxin alters arachidonate metabolism in pulmonary endothelial cells. Am. J. Physiol. 253:C384C390. 
37. Suttorp, N., W. Seeger, J. Uhl, F. Lutz, and L. Roka. 1985. Pseudomonas aeruginosa cytotoxin stimulates prostacyclin production in cultured pulmonary artery endothelial cells: membrane attack and calcium influx. J. Cell. Physiol. 123:64-72.

38. Suttorp, N., W. Toepfer, and L. Roka. 1986. Antioxidant defense mechanisms of endothelial cells: glutathione redox cycle versus catalase. Am. J. Physiol. 251:C671-C680.

39. Suttorp, N., W. Seeger, S. Zinsky, and S. Bhakdi. 1987. Complement complex $\mathrm{C} 5 \mathrm{~b}-8$ induces $\mathrm{PGI}_{2}$ formation in cultured endothelial cells. $\mathrm{Am}$. $\mathrm{J}$. Physiol. 253:C13-C22.

40. Norgauer, J., E. Kownatzki, R. Seifert, and K. Aktories. 1988. Botulinum $\mathrm{C} 2$ toxin ADP-ribosylates actin and enhances $\mathrm{O}_{2}$-production and secretion but inhibits migration of activated human neutrophils. J. Clin. Invest. 82:1376-1382.

41. Lammli, U. K. 1970. Cleavage of structural proteins during the assembly of bacteriophages T4. Nature (Lond.). 227:680-685.

42. Bradford, M. 1976. A rapid and sensitive method for the quantitation of microgram quantities of protein utilizing the principle of protein-dye binding. Anal. Biochem. 72:248-254.

43. Blikstad, I., F. Markey, L. Carlsson, T. Persson, and U. Lindberg. 1978. Selective assay of monomeric and filamentous actin in cell extracts, using inhibition of deoxyribonuclease I. Cell. 15:935-943.

44. Hinshaw, D. B., B. C. Armstrong, J. M. Burger, T. F. Beals, and P. A. Hyslop. 1988. ATP and microfilaments in cellular oxidant injury. Am. J. Pathol. 132:479-488.

45. Cabaud, P. G., and F. Wroblewski. 1958. Colorimetric measurement of lactic dehydrogenase activity of body fluid. Am. J. Clin. Pathol. 30:234-238.

46. Suttorp, N., T. Fuchs, W. Seeger, A. Wilke, and D. Drenckhan. 1989. Role of $\mathrm{Ca}^{2+}$ and $\mathrm{Mg}^{2+}$ for endothelial permeability of water and albumin in vitro. $L a b$. Invest. 61:183-191.

47. Dunn, O. J., and V. A. Clark. 1974. Applied Statistics: Analysis of Variance and Regression. John Wiley and Sons, New York.
48. Coluccio, L. M., and L. G. Tilney. 1984. Phalloidin enhances actin assembly by preventing monomer dissociation. J. Cell Biol. 99:529-535.

49. Estes, J. E., L. A. Selden, and L. C. Gershman. 1981. Mechanism of action of phalloidin on the polymerization of muscle actin. Biochemistry. 20:708-712.

50. Cooper, J. A. 1987. Effects of cytochalasins and phalloidin on actin. J. Cell Biol. 105:1473-1478.

51. Brenner, S. L., and E. D. Korn. 1980. The effects of cytochalasins on actin polymerization and actin ATPase provide insights into the mechanism of polymerization. J. Biol. Chem. 255:841-844.

52. Casella, J. F., M. D. Flanagan, and S. Lin. 1981. Cytochalasin D inhibits actin polymerization and induces depolymerization of actin filaments formed during platelet shape change. Nature (Lond.). 293:302-305.

53. Bershadsky, A. D., and J. M. Vasiliev. 1988. Components of cytoskeleton. In Cytoskeleton. A. D. Bershadsky, and J. M. Vasiliev, editors. Plenum Publishing Corp., New York. 13-78.

54. Aktories, K., K.-H. Reuner, P. Presek, and M. Bărmann. 1989. Botulinum $\mathrm{C} 2$ toxin treatment increases the G-actin pool in intact chicken cells: a model for the cytopathic action of actin-ADP-ribosylating toxins. Toxicon. 27:989-993.

55. Alexander, J. S., H. B. Hechtman, and D. Shepro. 1988. Phalloidin enhances endothelial barrier function and reduces inflammatory permeability in vitro. Microvasc. Res. 35:308-315.

56. Füssle, R. S. Bhakdi, A. Sziegoleit, J. Tranum-Jensen, T. Kranz, and H. J. Wellensiek. 1981. On the mechanisms of membrane damage by staphylococcus aureus alpha-toxin. J. Cell Biol. 91:83-94.

57. Volberg, T., B. Geiger, J. Kartenbeck, and W. W. Franke. 1986. Changes in membrane-microfilament interaction in intercellular adherens junctions upon removal of extracellular $\mathrm{Ca}^{2+}$ ions. J. Cell Biol. 102:1832-1842.

58. Madara, J. L., R. Moore, and S. Carlson. 1987. Alterations of intestinal tight junction structure and permeability by cytoskeletal contraction. Am. J. Physiol. 253:C854-C861

59. Niggli, V., and M. M. Burger. 1987. Interaction of the cytoskeleton with the plasma membrane. J. Membr. Biol. 100:97-121. 